\title{
Recommendations on prevention and screening for colorectal cancer in Hong Kong
}

\author{
Cancer Expert Working Group on Cancer Prevention and Screening
}

\section{A B S T R A C T}

Colorectal cancer is the commonest cancer in Hong Kong. The Cancer Expert Working Group on Cancer Prevention and Screening was established in 2002 under the Cancer Coordinating Committee to review local and international scientific evidence, assess and formulate local recommendations on cancer prevention and screening. At present, the Cancer Expert Working Group recommends that averagerisk individuals aged 50 to 75 years and without significant family history consult their doctors to consider screening by: (1) annual or biennial faecal occult blood test, (2) sigmoidoscopy every 5 years, or (3) colonoscopy every 10 years. Increased-risk individuals with significant family history such as those with a first-degree relative diagnosed with colorectal cancer at age $\leq 60$ years; those who have more than one first-degree relative diagnosed with colorectal cancer irrespective of age at diagnosis; or carriers of genetic mutations associated with familial adenomatous polyposis or Lynch syndrome should start colonoscopy screening earlier in life and repeat it at shorter intervals.

Hong Kong Med J 2018;24:521-6 DOI: 10.12809/hkmj177095

Cancer Expert Working Group on Cancer Prevention and Screening * (Group members are listed at the end of paper)

*Corresponding author: regina_ching@dh.gov.hk

\section{Introduction}

In Hong Kong, the Cancer Coordinating Committee is a high-level committee chaired by the Secretary for Food and Health to steer the direction of work on prevention and control of cancer. Under the Cancer Coordinating Committee, the Cancer Expert Working Group (CEWG) on Cancer Prevention and Screening was established in 2002 to review local and international scientific evidence and practices with a view to making recommendations on cancer prevention and screening suitable for Hong Kong.

This article details the local burden and prevention of colorectal cancer (CRC), and explains the rationale underpinning the current CEWG recommendations on CRC screening, which were reaffirmed and updated in 2017.

\section{Local epidemiology}

Colorectal cancer is the commonest cancer in Hong Kong. According to the Hong Kong Cancer Registry, there were 5036 newly registered CRC cases in 2015, representing $16.6 \%$ of all new cancer cases. ${ }^{1}$ The agestandardised incidence rates were 41.5 per 100000 population for men and 26.2 per 100000 population for women. ${ }^{1}$ The median age at diagnosis of CRC was 68 years in men and 70 years in women. ${ }^{1}$ The agespecific incidence rates increased significantly from age 50 years. Colorectal cancer is more common in men with the male-to-female ratio of 1.3:1 for new cases in $2015 .^{1}$
The Death Registry registered 2089 deaths caused by CRC in 2016, representing $14.7 \%$ of all cancer deaths and ranking it the second leading cause of cancer deaths in Hong Kong. ${ }^{2}$ The agestandardised mortality rates were 18.0 per 100000 population for men and 10.5 per 100000 population for women. ${ }^{2}$ After adjusting for the effect of population ageing, the age-standardised incidence rates for both sexes still showed an upward trend, whereas the age-standardised mortality rates for both sexes have remained stable for more than 30 years. $^{2}$

\section{Risk factors}

Risk factors for developing CRC may be modifiable or non-modifiable. Modifiable risk factors are those that are related to lifestyle, such as physical inactivity, low fibre intake, consumption of red meat or processed meat, overweight or obesity, smoking, and alcohol use. The World Health Organization's International Agency for Research on Cancer classifies consumption of processed meat as "carcinogenic to humans (Group I)," and consumption of red meat as "probably carcinogenic to humans (Group 2A)" and indicated that every 50 -g portion of processed meat eaten daily increases the risk of CRC by about $18 \% .{ }^{3}$ Conversely, the risk of CRC is inversely associated with intake of fibre. ${ }^{4}$ In addition, the International Agency for Research on Cancer considered that there is sufficient evidence to classify alcoholic beverage and tobacco smoking 


\section{香港的大腸癌預防及篩查建議}

癌症預防及普查專家工作小組

大腸癌是香港最常見的癌症。「癌症事務統籌委員會」轄下的「癌症 預防及普查專家工作小組」（專家工作小組）於2002年成立，負責檢 視本港及國際間的科學證據, 以便評估和制定適用於本地情况的癌症 預防及普查建議。現時, 專家工作小組建議年齡介乎 50 歲至 75 歲及沒 有明顯家族史的一般風險人士應與醫生商討, 考慮使用以下任何一種 方法進行大腸癌節查：(1) 每 1 至 2 年接受一次大便隱血測試、 (2) 每5年接受一次乙狀結腸鏡檢查, 或 $(3)$ 每 10 年接受一次大晹鏡檢 查。至於有明顯家族史的較高風險人士，例如有一位直系親屬於 60 歲 或之前患上大腸癌、多於一位直系親屬患上大腸癌 ( 不論確診時的年 齡），或帶有家族性大腸腺瘜肉病或連氏綜合症突變基因的人士，應 及早及更頻密地進行大腸癌節查。 as carcinogenic to humans in the development of CRC. ${ }^{5}$ Separately, the World Cancer Research Fund/ American Institute for Cancer Research reported that being overweight or obese can increase the risk of CRC, whereas increased physical activity is associated with reduction in risk. ${ }^{6}$

Non-modifiable risk factors include ageing, male gender, positive family history, history of familial adenomatous polyposis, Lynch syndrome (previously known as hereditary non-polyposis CRC), colonic polyp, and ulcerative colitis.

Based on local epidemiology, CRC is more common in men and its risk increases significantly from age 50 years. ${ }^{1}$ Regarding family history, according to a local study, $80 \%$ to $90 \%$ of CRC cases are sporadic, and the remaining $10 \%$ to $20 \%$ are familial cancers. ${ }^{7}$ The cancer risk of individuals with a positive family history may vary according to the age of diagnosis of CRC in the index patient and the number of affected first-degree relatives. The younger the age of diagnosis of CRC in the index patient, the higher the risk of CRC of family members would be. In a meta-analysis, the estimated relative risk of individuals with relatives diagnosed with CRC at age $<50$ years was 3.55 , whereas that for relatives diagnosed with CRC at age $\geq 50$ years was 2.18 . $^{8}$

Familial adenomatous polyposis is an autosomal dominant disorder caused by germline mutation of the adenomatous polyposis coli gene located on the short arm of chromosome 5 (5q2122). ${ }^{9}$ Individuals with this mutation have a $95 \%$ chance of developing CRC by age 50 years. ${ }^{10}$ Lynch syndrome is another dominantly inherited CRC syndrome. It is caused by germline mutation in one of the genes responsible for the repair of mismatches during DNA replication. The lifetime risk of $\mathrm{CRC}$ for those carrying this mutation is estimated to be $50 \%$ to $80 \%{ }^{10}$
Ulcerative colitis has been associated with an increased risk of developing CRC, likely caused by long-standing chronic inflammation. ${ }^{11}$ Moreover, CRC arises predominantly from adenomatous polyps, which can develop into CRC after $\geq 10$ years. ${ }^{12}$ Development of larger polyps, villous histology, and severe dysplasia are important indicators for progression into CRC. ${ }^{13}$

\section{Primary prevention}

Primary prevention is of utmost importance for the prevention of CRC as many of the risk factors are modifiable. For preventing CRC, the CEWG recommends:

- increasing intake of dietary fibre (eg, fibre from at least five servings of fruits and vegetables daily);

- decreasing consumption of red and processed meat;

- taking part in moderate-intensity aerobic physical activities for $\geq 150$ minutes per week;

maintaining a healthy body weight with body mass index between 18.5 to 22.9 and waist circumference $<80 \mathrm{~cm}$ for women and $<90 \mathrm{~cm}$ for men;

- avoiding or quitting tobacco smoking; and

- avoiding alcoholic drinks.

\section{Secondary prevention}

Secondary prevention involves screening individuals without symptoms in order to detect disease or identify individuals who are at increased risk of disease. Since CRC arises predominantly from precancerous adenomatous polyps developed over a long latent period, it is one of the few cancers that can be effectively prevented through organised and evidence-based screening. In general, for CRC screening, individuals can be classified into "average risk" and "increased risk" groups.

According to screening recommendations made by the CEWG, increased-risk individuals are those with a significant family history, such as an immediate relative diagnosed with CRC at age $\leq 60$ years; more than one immediate relatives diagnosed with CRC irrespective of age at diagnosis; or immediate relatives diagnosed with hereditary bowel diseases. Average-risk individuals are those aged 50 to 75 years who do not have the aforesaid family history.

\section{Screening for general population at average risk}

Since 2010, the CEWG has recommended that average-risk individuals aged 50 to 75 years should consult their doctors to consider one of the following screening methods:

- annual or biennial faecal occult blood test (FOBT); 
- $\quad$ sigmoidoscopy every 5 years; and

- colonoscopy every 10 years.

The CEWG made the above recommendations after taking into consideration local epidemiology, research evidence, as well as international guidelines and practices.

The age range recommended for CRC screening in the general population should be defined to capture the largest number of CRC cases while taking into account the efficacy and costeffectiveness of screening tests, local epidemiology, and anticipated benefits and harms to the screened population. In Hong Kong, the risk of CRC increases significantly from age 50 years. ${ }^{1}$ Guidelines in US ${ }^{14,15}$ and Singapore ${ }^{16}$ recommend starting screening at age 50 years, whereas guidelines in the UK recommend starting screening at age $>50$ years. ${ }^{17}$

Regarding screening modalities, FOBT, sigmoidoscopy and colonoscopy have been shown to reduce mortality from CRC. Faecal occult blood tests can decrease CRC mortality by $15 \%$ to $33 \%$, according to findings from large-scale randomised control trials. ${ }^{18-20}$ A Cochrane review showed that screening by FOBT might reduce CRC mortality in the average risk population by $16 \% .{ }^{21}$ Sigmoidoscopy has been shown to lead to a $28 \%$ risk reduction in overall CRC mortality and a $43 \%$ risk reduction in distal CRC mortality in a meta-analysis. ${ }^{22}$ Colonoscopy was associated with $61 \%$ reduction in CRC mortality in another meta-analysis. ${ }^{23}$

International guidelines and practices for CRC screening in the general population mainly recommend annual or biennial FOBT, sigmoidoscopy once every 5 years, or colonoscopy once every 10 years. ${ }^{15,16}$

To reduce the burden arising from $\mathrm{CRC}$, the government launched the 3-year Colorectal Cancer Screening Pilot Programme (Pilot Programme) on 28 September 2016 to provide subsidised screening by phases to average risk Hong Kong residents born in 1946 to 1955 (aged 61-70years in 2016). The screening workflow comprises two stages. Participants first receive a subsidised faecal immunochemical test (a new version of FOBT) from an enrolled primary care doctor. If the faecal immunochemical test result is positive, the participant receives a subsidised colonoscopy examination from a colonoscopy specialist enrolled in the Pilot Programme. In August 2018, the government regularised the programme and would progressively extend it to cover individuals aged 50 to 75 years. Details are available at http://www.colonscreen.gov.hk.

\section{Screening for increased-risk individuals}

In 2017, the CEWG updated the CRC screening recommendations for increased-risk individuals.
The key change was related to the interval for colonoscopy screening among individuals with significant family history of CRC but without genetic mutations.

- For carriers of genetic mutations associated with Lynch syndrome, the CEWG recommends screening for CRC by colonoscopy every 1 to 2 years from age 25 years.

- For carriers of genetic mutations associated with familial adenomatous polyposis, the CEWG recommends screening by sigmoidoscopy every 2 years from age 12 years.

- For individuals with one first-degree relative (offspring, sibling or parent) diagnosed with CRC at age $\leq 60$ years, or more than one first-degree relative with CRC irrespective of age at diagnosis, colonoscopy should be performed every 5 years (previously the recommendation was every 3 to 5 years). Colonoscopy should begin at age 40 years or 10 years prior to the age at diagnosis of the youngest affected relative, whichever is earliest, but not earlier than age 12 years.

For patients with CRC with identifiable genetic mutations, including Lynch syndrome and familial adenomatous polyposis, the CEWG recommends two-tier screening for their family members. Genetic testing should be conducted first, followed by endoscopic examination at specified and shorter intervals if the genetic test is positive. This reduces the number of unnecessary investigations among those with strong family history but without proven genetic mutation, decreasing the risk of potential complications arising from repeated endoscopic procedures.

These recommendations were made after considering the scientific evidence and international guidelines and practices.

Individuals who are carriers of genetic mutations associated with familial adenomatous polyposis or Lynch syndrome and individuals with a family history of CRC are at increased risk of CRC. Colorectal cancer in these individuals tends to be diagnosed at a younger age and progresses more aggressively than CRC in the general population. ${ }^{24,25}$

International recommendations emphasise that CRC screening in increased-risk individuals needs to start earlier in their lifetime and be repeated at shorter intervals. Recommendations made by countries and by professional organisations on screening for increased-risk individuals generally suggest the use of colonoscopy and sigmoidoscopy as the screening methods. ${ }^{15,16,26-32}$

The recommended endoscopic screening method for carriers of genetic mutations associated with Lynch syndrome is annual or biennial colonoscopy. It is recommended to start screening at age 20 to 25 years in the US ${ }^{15,26,27}$ and Singapore, ${ }^{16}$ at age 25 years in UK, ${ }^{28}$ and at age 25 years or 5 years 
earlier than the age at diagnosis of the youngest affected member of the family (whichever is the earliest) in Australia. ${ }^{29}$ The guidelines issued by the World Gastroenterology Organization (WGO) recommend that screening should start at age 20 to 25 years or 10 years earlier than the youngest age at CRC diagnosis in the family, whichever comes first. ${ }^{30}$

The recommended endoscopic screening method for carriers of genetic mutations associated with familial adenomatous polyposis is mainly annual or biennial flexible sigmoidoscopy, or annual colonoscopy. It is recommended to start screening at age 10 to 12 years in the US ${ }^{15}$ and Singapore, ${ }^{16}$ at age 13 to 15 years in the $U K,{ }^{28}$ and at age 12 to 15 years (later age is recommended) in Australia. ${ }^{29}$ The guidelines issued by the National Comprehensive Cancer Network suggest screening should start at age 10 to 15 years, ${ }^{31,32}$ whereas the WGO recommendation is to start screening at age 10 to 12 years. $^{30}$

International guidelines recommend endoscopic screening for individuals who have one first-degree relative diagnosed with CRC at age 50 to 60 years..$^{15,16,26,28-33}$ Individuals with more than one first-degree relative with CRC irrespective of age at diagnosis are considered at increased risk and endoscopic screening at more frequent intervals is recommended. ${ }^{15,16,26,28-32}$ For these individuals, the recommended endoscopic screening method is to receive colonoscopy every 5 years. ${ }^{15,16,26,29-32}$ It is recommended to start screening at age 40 to 50 years, or 10 years prior to the age at diagnosis of the youngest affected relative. ${ }^{15,16,26,29-32}$

Currently, patients with CRC may be referred for genetic counselling and testing. These services are provided at centres run by nongovernmental organisation, including the Hereditary Gastrointestinal Cancer Genetic Diagnosis
Laboratory (http://www.patho.hku.hk/colonreg. htm); the Department of Health's Clinical Genetic Service (http://www.dh.gov.hk); and the private sector. Although referral criteria for testing may differ among these testing services, commonly adopted criteria include strong family history, occurrence of multiple cancers in a single individual, early onset of disease, presence of pathogenic mutation in the cancer predisposition gene, and clinically suspected hereditary cancer syndrome.

\section{Emerging evidence for colorectal cancer screening}

In the past 2 years, new evidence supporting the effectiveness of CRC screening has emerged which reinforces the CEWG recommendations.

A systematic review reported that sigmoidoscopy is associated with a $27 \%$ reduction in CRC-specific mortality in four randomised controlled trials and that biennial FOBT screening reduced CRC-specific mortality by $9 \%$ to $22 \%$ at 19.5 to 30 years of follow-up in five randomised controlled trials compared with no screening in the average-risk population. ${ }^{34,35}$

Separately, a prospective study in Sweden found that colonoscopic surveillance for increasedrisk individuals with significant family history is a cost-effective intervention to prevent CRC. ${ }^{36}$

In addition, the US Preventive Services Task Force, ${ }^{37}$ the US Multi-Society Task Force on Colorectal Cancer Screening, ${ }^{38}$ and the American Cancer Society ${ }^{39,40}$ updated their recommendations for CRC screening in 2016 and 2017. All continue to recommend annual FOBT, sigmoidoscopy every 5 to 10 years, or colonoscopy every 10 years as appropriate screening modalities for average-risk individuals.

TABLE. Recommendations on CRC screening by the CEWG

\begin{tabular}{|c|c|}
\hline For asymptomatic average-risk individuals & For at increased-risk individuals \\
\hline $\begin{array}{l}\text { Recommendation on screening for CRC } \\
\text { - The CEWG recommends that all individuals aged } 50 \text { to } 75 \text { years } \\
\text { should consult their family doctor to consider CRC screening } \\
\text { by one of the following methods: faecal occult blood test every } \\
1 \text { or } 2 \text { years; sigmoidoscopy every } 5 \text { years; or colonoscopy } \\
\text { every } 10 \text { years. }\end{array}$ & $\begin{array}{l}\text { Recommendations on screening for CRC } \\
\text { - For carriers of genetic mutations associated with Lynch syndrome, the } \\
\text { CEWG recommends screening for CRC by colonoscopy every } 1 \text { to } 2 \text { years } \\
\text { from age } 25 \text { years. } \\
\text { - For carriers of genetic mutations associated with familial adenomatous } \\
\text { polyposis, the CEWG recommends screening by sigmoidoscopy every } 2 \\
\text { years from age } 12 \text { years. } \\
\text { - For individuals with one first-degree relative diagnosed with CRC at age } \\
\leq 60 \text { years, or more than one first-degree relative with CRC irrespective } \\
\text { of age at diagnosis, the CEWG recommends colonoscopy every } 5 \text { years } \\
\text { from age } 40 \text { years or } 10 \text { years prior to the age at diagnosis of the youngest } \\
\text { affected relative, but not earlier than age } 12 \text { years. } \\
\text { Recommendation on genetic testing for CRC } \\
\text { - For patients with CRC with identifiable genetic mutations, the CEWG } \\
\text { recommends offering their family members two-tier screening by } \\
\text { genetic testing followed by endoscopic examination, to reduce the } \\
\text { number of unnecessary investigations and to reduce the risk of potential } \\
\text { complications. }\end{array}$ \\
\hline
\end{tabular}




\section{Conclusion}

After considering local epidemiology, scientific evidence, and local and international screening guidelines and practices, the CEWG reaffirms in 2017 the CRC screening recommendations for averagerisk individuals and updates the screening interval relating to the recommendations for increased-risk individuals with significant family history of CRC, as summarised in the Table. A leaflet and booklet on the CEWG recommendations are available (http:// www.chp.gov.hk/en/content/9/25/31932.html) for downloading and dissemination to the general public to help them make informed choices. The CEWG will continue to monitor emerging local and international evidence and practice to ensure evidence-based CRC prevention and screening recommendations are up to date.

\section{Cancer Expert Working Group on Cancer Prevention and Screening (August 2016 to July 2018)}

1 TH Lam, MD

${ }^{2} \mathrm{KH}$ Wong, MB, BS, FHKAM (Medicine)

${ }^{3}$ Karen KL Chan, MBBChir, FHKAM (Obstetrics and Gynaecology)

${ }^{4}$ Miranda CM Chan, MB, BS, FHKAM (Surgery)

${ }^{5}$ David VK Chao, FRCGP, FHKAM (Family Medicine)

${ }^{6}$ Annie NY Cheung, MD, FHKAM (Pathology)

${ }^{7}$ Cecilia YM Fan, MB, BS, FHKAM (Family Medicine)

${ }^{8}$ Judy Ho, MB, BS, FHKAM (Surgery)

${ }^{9}$ EP Hui, MD (CUHK), FHKAM (Medicine)

${ }^{10}$ KO Lam, MB, BS, FHKAM (Radiology)

${ }^{11}$ CK Law, FHKCR, FHKAM (Radiology)

12 WL Law, MS, FHKAM (Surgery)

${ }^{13}$ Herbert HF Loong, MB, BS, FHKAM (Medicine)

${ }^{14}$ Roger KC Ngan, FRCR, FHKAM (Radiology)

15 Thomas HF Tsang, MB, BS, FHKAM (Community Medicine)

${ }^{16}$ Martin CS Wong, MD, FHKAM (Family Medicine)

${ }^{17}$ Rebecca MW Yeung, MD, FHKAM (Radiology)

${ }^{18}$ Anthony CH Ying, MB, BS, FHKAM (Radiology)

${ }^{19}$ Regina Ching, MB, BS, FHKAM (Community Medicine)

${ }^{1}$ School of Public Health, Li Ka Shing Faculty of Medicine, The University of Hong Kong, Hong Kong

${ }^{2}$ Department of Health, Hong Kong

${ }^{3}$ The Hong Kong College of Obstetricians and Gynaecologists, Hong Kong

${ }^{4}$ Hospital Authority (Surgical), Hong Kong

${ }^{5}$ The Hong Kong College of Family Physicians, Hong Kong

${ }^{6}$ The Hong Kong College of Pathologists, Hong Kong

${ }^{7}$ Professional Development and Quality Assurance, Department of Health, Hong Kong

${ }^{8}$ World Cancer Research Fund Hong Kong, Hong Kong

${ }^{9}$ Hong Kong College of Physicians, Hong Kong

${ }^{10}$ Department of Clinical Oncology, The University of Hong Kong, Hong Kong

${ }^{11}$ Hong Kong College of Radiologists, Hong Kong

12 The College of Surgeons of Hong Kong, Hong Kong

${ }^{13}$ Department of Clinical Oncology, The Chinese University of Hong Kong, Hong Kong

${ }^{14}$ Hong Kong Cancer Registry, Hospital Authority, Hong Kong
${ }^{15}$ Hong Kong College of Community Medicine, Hong Kong

${ }^{16}$ The Jockey Club School of Public Health and Primary Care, The Chinese University of Hong Kong, Hong Kong

${ }^{17}$ Hospital Authority (Non-surgical), Hong Kong

18 The Hong Kong Anti-Cancer Society, Hong Kong

${ }^{19}$ Centre for Health Protection, Department of Health, Hong Kong

\section{Author contributions}

All authors have made substantial contributions to the concept or design; acquisition of data; analysis or interpretation of data; drafting of the article; and critical revision for important intellectual content.

\section{Declaration}

As editors of this journal, DVK Chao, HHF Loong, and MCS Wong were not involved in the peer review process of this article. All authors have no conflicts of interest to disclose. All authors had full access to the data, contributed to the study, approved the final version for publication, and take responsibility for its accuracy and integrity. An earlier version of this article was published online on the Centre for Health Protection website (https://www.chp.gov.hk/files/pdf/cewg_ crc_professional_hp.pdf).

\section{References}

1. Hong Kong Cancer Registry. Colorectal cancer in 2015. 2016. Available from: http://www3.ha.org.hk/cancereg/ pdf/factsheet/2015/colorectum_2015.pdf. Accessed 31 Oct 2017.

2. Department of Health and Census and Statistics Department, Hong Kong SAR Government. Mortality Statistics; 2016.

3. World Health Organization. Q\&A on the carcinogenicity of the consumption of red meat and processed meat. 2015. Available from: http://www.who.int/features/qa/cancerred-meat/en/. Accessed 6 Sep 2017.

4. Bradbury KE, Appleby PN, Key TJ. Fruit, vegetable, and fiber intake in relation to cancer risk: findings from the European Prospective Investigation into Cancer and Nutrition (EPIC). Am J Clin Nutr 2014;100(Suppl 1):394S398 S.

5. International Agency for Research on Cancer, World Health Organization. List of classifications by cancer sites with sufficient or limited evidence in humans, Vol 1 to 121. 2018. Available from: https://monographs.iarc.fr/ENG/ Classification/Table4.pdf. Accessed 6 Sep 2017.

6. World Cancer Research Fund and American Institute for Cancer Research. Diet, Nutrition, Physical Activity and Colorectal Cancer. World Cancer Research Fund International; 2017.

7. Ho JW, Yuen ST, Lam TH. A case-control study on environmental and familial risk factors for colorectal cancer in Hong Kong: chronic illnesses, medication and family history. Hong Kong Med J 2006;12(Suppl 1):S14-6.

8. Butterworth AS, Higgins JP, Pharoah P. Relative and absolute risk of colorectal cancer for individuals with a family history: a meta-analysis. Eur J Cancer 2006;42:21627.

9. Half E, Bercovich D, Rozen P. Familial adenomatous polyposis. Orphanet J Rare Dis 2009;4:22.

10. Samadder NJ, Jasperson K, Burt RW. Hereditary and 
common familial colorectal cancer: evidence for colorectal screening. Dig Dis Sci 2015;60:734-47.

11. Castaño-Milla C, Chaparro M, Gisbert JP. Systematic review with meta-analysis: the declining risk of colorectal cancer in ulcerative colitis. Aliment Pharmacol Ther 2014;39:645-59.

12. Winawer SJ. Natural history of colorectal cancer. Am J Med 1999;106:3S-6S

13. Terry MB, Neugut AI, Bostick RM, et al. Risk factors for advanced colorectal adenomas: a pooled analysis. Cancer Epidemiol Biomarkers Prev 2002;11:622-9.

14. Agency for Healthcare Research and Quality, Department of Health \& Human Services, US Government. US Preventive Services Task Force. Screening for Colorectal Cancer: Summary of Recommendations. October 2008. Available from: http://www.ahrq.gov/clinic/uspstf/ uspscolo.htm. Accessed 8 Oct 2008.

15. Levin B, Lieberman DA, McFarland B, et al. Screening and surveillance for the early detection of colorectal cancer and adenomatous polyps, 2008: a joint guideline from the American Cancer Society, the US Multi-Society Task Force on Colorectal Cancer, and the American College of Radiology. CA Cancer J Clin 2008;58:130-60.

16. Ministry of Health, Singapore Government. Cancer Screening: MOH Clinical Practice Guidelines 1/2010, February 2010.

17. The UK NSC recommendation on bowel cancer screening Available from: https://legacyscreening.phe.org.uk/ bowelcancer. Accessed 10 Sep 2018.

18. Hardcastle JD, Chamberlain JO, Robinson $\mathrm{MH}$, et al. Randomised controlled trial of faecal-occult-blood screening for colorectal cancer. Lancet 1996;348:1472-7.

19. Kronborg O, Fenger C, Olsen J, Jørgensen OD, Søndergaard O. Randomised study of screening for colorectal cancer with faecal-occult-blood test. Lancet 1996;348:1467-71.

20. Mandel JS, Bond JH, Church TR, et al. Reducing mortality from colorectal cancer by screening for fecal occult blood. Minnesota colon cancer control study. N Engl J Med 1993;328:1365-71.

21. Hewitson P, Glasziou P, Irwig L, Towler B, Watson E. Screening for colorectal cancer using the faecal occult blood test, Hemoccult. Cochrane Database Syst Rev 2007;(1):CD001216.

22. Shroff J, Thosani N, Bartra S, Singh H, Guha S. Reduced incidence and mortality from colorectal cancer with flexible-sigmoidoscopy screening: a meta-analysis. World J Gastroenterol 2014;20:18466-76.

23. Pan J, Xin L, Ma YF, Hu LH, Li ZS. Colonoscopy reduces colorectal cancer incidence and mortality in patients with non-malignant findings: a meta-analysis. Am J Gastroenterol 2016;111:355-65.

24. Winawer SJ, Fletcher RH, Miller L, et al. Colorectal cancer screening: clinical guidelines and rationale. Gastroenterology 1997;112:594-642.

25. Rose P, Dunlop M, Burton H, Haites N. Screening for late onset genetic disorders colorectal cancer. The UK National Screening Committee; October 2000.

26. Rex DK, Johnson DA, Anderson JC, et al. American College of Gastroenterology guidelines for colorectal cancer screening 2009 [corrected]. American J Gastroenterol 2009;104:739-50.

27. Giardiello FM, Allen JI, Axilbund JE, et al. Guidelines on genetic evaluation and management of Lynch syndrome: a consensus statement by the US Multi-Society Task Force on Colorectal Cancer. Am J Gastroenterol 2014;109:115979.

28. Cairns SR, Scholefield JH, Steele RJ, et al. Guidelines for colorectal cancer screening and surveillance in moderate and high risk groups (update from 2002). Gut 2010;59:66689

29. National Health and Medical Research Council, Australia Government. Clinical Practice Guidelines: The Prevention, Early Detection and Management of Colorectal Cancer; December 2005.

30. Winawer S, Classen M, Lambert $\mathrm{R}$, et al. World Gastroenterology Organisation/International Digestive Cancer Alliance Practice Guidelines: Colorectal Cancer Screening. South African Gastroenterology Review 2008;6.

31. National Comprehensive Cancer Network. NCCN Clinical Practice Guidelines in Oncology: Rectal Cancer Version 2; 2016.

32. National Comprehensive Cancer Network. NCCN Clinical Practice Guidelines in Oncology: Colon Cancer Version 1; 2017.

33. Sung JJ, Ng SC, Chan FK, et al. An updated Asia Pacific consensus recommendations on colorectal cancer screening. Gut 2015;64:121-32.

34. Lin JS, Piper MA, Perdue LA, et al. Screening for colorectal cancer: updated evidence report and systematic review for the US preventive services task force. JAMA 2016;315:2576-94.

35. Lin JS, Piper MA, Perdue LA, et al. Screening for colorectal cancer: a systematic review for the US preventive services task force. Evidence synthesis No. 135. Agency for Healthcare Research and Quality; 2016.

36. Sjöström O, Lindholm L, Melin B. Colonoscopic surveillance-a cost-effective method to prevent hereditary and familial colorectal cancer. Scand J Gastroenterol 2017;52:1002-7.

37. US Preventive Services Task Force, Bibbins-Domingo K, Grossman DC, et al. Screening for colorectal cancer: US preventive services task force recommendation statement. JAMA 2016;315:2564-75.

38. Rex DK, Boland CR, Dominitz JA, et al. Colorectal cancer screening: recommendations for physicians and patients from the US multi-society task force on colorectal cancer. Gastroenterology 2017;153:307-23.

39. American Cancer Society. American Cancer Society recommendations for colorectal cancer early detection. July 2017. Available from: https://www.cancer.org/cancer/ colon-rectal-cancer/detection-diagnosis-staging/acsrecommendations.html. Accessed 6 Sep 2017.

40. Smith RA, Andrews KS, Brooks D, et al. Cancer screening in the United States, 2017: a review of current American Cancer Society guidelines and current issues in cancer screening. CA Cancer J Clin 2017;67:100-21. 